\title{
Seventh Annual Winter Neuropeptide Conference
}

The Winter Neuropeptide Conference will be held in Breckenridge, Colorado, January 20 through January 24, 1986. As in past years, the Conference is intended to be an informal context in which to present and discuss basic and clinical research of high quality related to neuropeptide biology. Areas of discussion will include regulation of synthesis and metabolism, as well as effects of peptides at various levels of organization, from the molecular to the behavioral. Proposals for symposia and workshops should be received by October 1, 1985, and abstracts for poster sessions by November 1,1985 . A $\$ 500$ award will be presented to the most outstanding manuscript submitted by a postdoctoral fellow (deadline for receipt November 1, 1985). Abstracts and inquiries should be sent to:

Donald R. Britton

Department of Physiology

School of Medicine

University of New Mexico

Albuquerque, NM 87131

\section{Search for Photographic Material-Karl Bühler}

The editors of the complete works of Professor Karl Bühler wish to augment the edition with a generously illustrated biography. When Karl Bühler was expelled by the Nazis, he had to leave all his possessions in Vienna. Consequently, his literary legacy contains very few photographs, and these make up the core of our collection. We are interested in any pictures of Karl Bühler, either private, personal ones or ones taken at public events such as lectures or congresses or with his fellow students, staff, or colleagues. If you know of the existence of such photographs which could be lent to the project, please contact:

\author{
Bühler Editions Project \\ Professor Achim Eschbach \\ Universität GH Essen \\ Fachbereich 4 \\ Universitätsstrasse \\ D-4300 Essen, West Germany \\ Tel: (0201) 183-3303
}

